the abdominoplasty masked the level of block, as tested over the abdomen, and could have led to a mistaken belief that the epidural was not working or that a larger increment of local anaesthetic was required.

These two cases are unusual in the presentation of their regional block. However, knowing the anatomy of the one case and the past surgical history in the other it is easy to postulate a mechanism for the clinical picture.

M. Joanne Douglas MD FRCPC

Department of Anaesthesia

British Columbia's Women's Hospital and

Health Centre Society

\section{Vasopressors and hypotension}

To the Editor:

We read with interest Dr. P. Morgan's review entitled "The role of vasopressors in the management of hypotension induced by spinal and epidural anaesthesia" (Can J Anaesth 1994: 41; 404-13) and would like to make the following comments.

There was no mention of the role played by the venous system in the genesis of hypotension during spinal blockade. Greene and Brull, ${ }^{1}$ Macrae and Wildsmith ${ }^{2}$ and our own findings ${ }^{3}$ all report that venous capacitance is increased during spinal blockade. Greene and Brulls'l view was that venodilation causes a reduction in venous return to the heart and this is one of main factors causing hypotension. They strongly recommend the use of headdown tilt during spinal blockade to improve venous return. Our experience with elderly patients receiving subarachnoid block is that a moderate decrease in central venous pressure occurs, on average $2.5 \mathrm{~cm} \mathrm{H}_{2} \mathrm{O}$, and this can be adequately reversed, in most cases, by giving $8 \mathrm{ml} \cdot \mathrm{kg}^{-1}$ colloid during the induction phase of the block. $^{3}$

Dr. Morgan contradicts himself when discussing the use of ephedrine. He mentions that ephedrine has both $\alpha$ and $\beta$-adrenergic agonist actions and the "vasocontriction is almost balanced by vasodilatation, and peripheral resistance is usually little changed." Later he states that ephedrine is capable of increasing cardiac output and of increasing peripheral resistance. We think that Dr. Morgan alludes to the fact that agonists with both $\alpha$ and $\beta$ simulating activity, such as ephedrine, are poor vasoconstrictors because of the opposing effects of simultaneous $\alpha$ (vasoconstriction) and $\beta$ (vasodilatation) stimulation on the arterial beds. ${ }^{4}$ We found the same results in treating hypotension during subarachnoid block with ephedrine infusion in 30 elderly patients. ${ }^{5}$
Dr. Morgan refers to metaraminol as having both $\alpha$ and $\beta$ stimulatory effects. This is misleading as the clinical effects of metaraminol are predominantly alpha. We have used metaraminol during subarachnoid block for several years and consider the dose of $5 \mathrm{mg} i v$ to be excessive, despite being frequently quoted. 6,7 In the non-obstetric elderly patient undergoing subarachnoid block, our current practice, after giving a moderate volume of colloid $\left(8 \mathrm{ml} \cdot \mathrm{kg}^{-1}\right)$, is to treat hypotension with a bolus of $0.5-1.0 \mathrm{mg}\left(0.1-0.2 \mathrm{mg} \cdot \mathrm{kg}^{-1}\right)$ followed by an infusion of $10 \mathrm{mg}$ in $20 \mathrm{ml}$ of normal saline run at $5-10 \mathrm{ml} \cdot \mathrm{hr}^{-1}$. Our experience with this dose is that metaraminol is highly effective at restoring preload and afterload during subarachnoid block but has little demonstrable effect on heart rate or contractility. ${ }^{8}$

\section{L.A.H. Critchley mB ChB FFARCI \\ F. Conway MB ChB FFARCI}

T.G. Short MB ChB MD FANZCA

Department of Anaesthesia and Intensive Care

Prince of Wales Hospital

The Chinese University of Hong Kong

Shatin, N.T., Hong Kong

\section{REFERENCES}

1 Greene NM, Brull SJ. The cardiovascular system. In: Greene NM, Brull SJ (Eds.). Physiology of Spinal Anaesthesia, 4th ed., Baltimore: Williams \& Wilkins, 1993: 85-177.

2 McCrae AF, Wildsmith JA. Prevention and treatment of hypotension during central neural block. Br $\mathrm{J}$ Anaesth 1993; 70: 672-80.

3 Critchley LA, Stuart JC, Short TG, Gin T. The haemodynamic effects of subarachnoid block in elderly patients: measurement by transthoracic bioimpedance. $\mathrm{Br} \mathrm{J}$ Anaesth (in press).

4 Stoelting $R K$. Sympathomimetics. In: Stoelting, R.K. (Ed.). Pharmacology \& Physiology in Anesthetic Practice, 2nd Ed. Philadelphia: J.B. Lippincott, 1991; 264-79.

5 Critchley LA, Stuart JC, Conway F, Short TG. Hypotension during subarachnoid anaesthesia: haemodynamic effects of ephedrine. $\mathrm{Br} \mathbf{J}$ Anaesth (in press).

6 Hoffman B, Lefkowitz $R$. Catecholamines and sympathomimetic drugs. In: Gilman A, Rall T, Nies A, Taylor $P$ (Eds.). The Pharmacological Basis of Therapeutics, 8th ed., Singapore: Pergamon Press, 1991: 213-4.

7 Sympathomimetics. In: Reynolds JE, Parfitt K (Eds.). Martindale, the Extra Pharmacopoeia, 29th ed., London: The Pharmaceutical Press 1989: 1468-89.

8 Critchley $L A$, Short TG, Gin T. Hypotension during subarachnoid anaesthesia: haemodynamic analysis of three treatments. Br J Anaesth 1994; 72: 151-5. 